ISSN 2504-1916

VoL. 16/1 (2017), 13-22

\title{
Moving to Higher Ground
}

\section{The Changing Discourse of European Jazz 1960-1980}

Tony Whyton

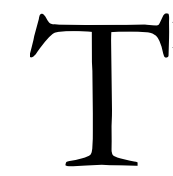

he 2014 conference 'Growing Up: Jazz between 1960 and 1980' in Lucerne provided a stimulating environment for the examination of European identity in jazz, and offered several fascinating insights into the musical landscape and changing cultural discourses of jazz during this period in history. The overarching theme of the Conference-'Growing Up'-occupied my thoughts a lot both during the event and in putting this article together, as the concept itself brings with it certain assumptions about the maturing of an art form and the progress of history. The theme itself offered the perfect platform to interrogate concepts of history and value in jazz and provided a way in to understanding how the identity of jazz in Europe has changed over time and is continually negotiated.

In this article, I suggest that the idea of 'Growing Up' encourages a way of thinking about jazz's place in Europe that is problematic; the concept invests in the belief in linear historical progress and causal narration, the promotion of a developing artistic sensibility, and the idea of a maturation of form where jazz 'comes of age'. In effect, whilst it is important to consider the historical development of music and its changing reception through time, the concept of growing up reinforces a number of assumptions about art music and its place in European culture; it has the ability to shape how we view the movement of music and culture, what social and cultural changes might have occurred during the period we're looking at, and promotes a particular view of European jazz and its relationship both to the American jazz tradition and popular culture more broadly.

In approaching this article, therefore, I've been thinking about ways of understanding jazz through the lens of growing up, exploring what it means for jazz in Europe to be grown up, and looking back in time to examine ways of articulating the changing discourse of jazz music in Europe between 1960 and 1980. As a way of structuring my thoughts on the theme, I want to riff on the idea of growing up through four separate, yet integrally related, headings, in order to shed light on some of the issues that have been central to understandings of jazz in Europe today. These headings are by no means exhaustive but provide us with a useful way in to considering the broader issues at play when jazz is framed in this way. 


\section{Finding a European Voice}

The idea of growing up in itself can infer several different but related meanings. We can think of growing up as reaching a form of maturity, where jazz in its European form comes of age. This is aligned with the idea of European jazz musicians and national jazz scenes finding their own voice or 'emancipating themselves from American role models', as it stated in the publicity materials for the Lucerne conference. This is a view of European jazz as depicted in Julian Benedikt's 2006 documentary, Play Your Own Thing, which provides an overview of the history of jazz in Europe through a loose set of themes, ranging from an examination of the role of jazz as an emblem for freedom and democracy to the fetishisation of African American bodies where jazz musicians are exoticised and revered romantically. The teleology of Benedikt's film leads to a closing sequence where the Polish trumpeter Tomasz Stańko completes a recording session for the ECM label; in terms of the narrative of the film, we have arrived at a point where European jazz comes of age and stands on its own. The closing sequences of the film move immediately from Stańko describing his level of peace and attainment as a musician working with Manfred Eicher's ECM as a type of 'ideal living' to a visual sequence which features frozen landscapes of Scandinavia accompanied by the spoken voice of Jan Garbarek. These landscapes and Garbarek's voice are used throughout the film as a narrative strategy. Garbarek is the narrator for the entire film, whose voice clearly forms part of the trajectory of the film. Indeed, Garbarek is only revealed visually at the end of the film as a sign of the 'Coming of Age' of European jazz. In Benedikt's film, ECM and the concept of the 'Nordic Tone' come to embody the essence of European jazz and, through Garbarek, we are encouraged to believe that this is what it means to 'play your own thing'. Finally, European jazz is portrayed as being disconnected from the US influence, and the director uses a quote from Garbarek about not playing like Charlie Parker to begin and end the film. Overall, the documentary presents us with the idea that there is a different sensibility coming from Europe today; in finding their voice, European jazz musicians have severed their links to America.

The themes of Play Your Own Thing echo general media coverage and research work over recent years in which European jazz is examined and analysed as offering something different; a new sensibility has emerged as European jazz scenes have been said to have 'grown up'. Writings ranging from Stuart Nicholson's Is Jazz Dead? Or Has It Moved to a New Address' to Mike Heffley's Northern Sun, Southern Moon: Europe's Reinvention of Jazz promoted the qualities of European jazz and signalled the emergence of new voices—or centres of jazz — that appear to exist outside the confines of the American mainstream. Within this context, Garbarek-an artist most readily associated with Nordic sound—could be said to form part of a new creation myth for jazz.

1 Julian Benedikt, Play Your Own Thing: The Story of Jazz in Europe (Benedikt Pictures/Euroarts DVD ASIN: B000T90ZA2, 2007).

2 Stuart Nicholson, Is Jazz Dead? Or Has It Moved to a New Address (New York: Routledge, 2005).

3 Mike Heffley, Northern Sun, Southern Moon: Europe's Reinvention of Jazz (New Haven: Yale University Press, 2005). 
Coupled with this, a number of national jazz agencies in Europe have been keen to document their own jazz traditions and to construct and celebrate the contribution of local jazz musicians to a national music narrative. ${ }^{4}$ Therefore, this first take on the theme of growing up might serve to explain the emergence of supposedly national jazz sounds and sensibilities during this period, and in places where the histories of jazz in European countries have been documented and constructed. ${ }^{5}$ But this approach to growing up also triggers highly romanticised narratives. Indeed, from my perspective, any claim to the emancipation of jazz from American influences is problematic and misunderstands the complexity of cultural influence and exchange, as I discuss below.

\section{Recognition and social acceptance}

In addition to the idea of discovering one's voice, we can also think of growing up in relation to taking things seriously and being taken seriously. As we mature, we're no longer carefree and prone to mischief making-it's time to grow up, to become respectable, legitimate, and to be accepted into a society. When thinking of jazz in relation to this idea, we can see several examples of the music being presented as more socially acceptable. In the UK, for example, it was not until the late 1960s and 1970s that the ground began to shift in terms of the development of an infrastructure for jazz in Britain with the creation of education programmes, the development of support organisations for jazz, and the recognition of the music by some public bodies. The Jazz Centre Society, for example, was founded in 1968 as a body which sought to establish a permanent centre for jazz in London, serving to elevate the music's national standing. Although a permanent home for the Centre was not established and the society was disbanded in the early 1980s, the legacy of the group continued in the form of Jazz Services, a national organisation which, until April 2015, remained the main support body for jazz musicians and promoters in Britain. Founded in 1945, the Arts Council's first award to jazz was not given until the late 1960s and the funding of jazz-based projects, venues and festivals continued at a slow and steady rate until the 1980s. ${ }^{6}$ This infrastructural shift is mirrored in different European contexts albeit with varying rates of change and success. These developments show a gradual acceptance of jazz within the cultural sector, although the place of jazz and recognition of the music's importance within national cultures continues to be debated and contested today. For example, in July 2014, the writer and music critic Ivan Hewett published an

4 For example, see the history pages of national jazz agencies such as 'Svensk Jazz', accessed 20 October 2017, www.svenskjazz.se/en/om-oss/historik2, and 'Jazzdanmarsk Jazzhistorie', Jazz Danmark, accessed 20 October 2017, www.jazzdanmark.dk/da/jazzhistorie/jazzdanmarks-jazzhistorie.

5 For an overview of the way in which jazz has been constructed and fed into national settings in different European settings see Jaziforschung 42 (2010) and Luca Cerchiari, Laurent Cugny, and Franz Kerschbaumer, eds., Eurojazzland: Jazz and European Sources, Dynamics, and Contexts (Boston: Northeastern University Press, 2012).

6 For further information on the changing infrastructure for jazz in Britain see Tony Whyton, Jazz Research in Britain', Jaz:forschung 42 (2010): 129-145 
article entitled 'Jazz: The Cinderella of Arts Funding' in The Telegraph that attempted to account for why jazz as an art form was not funded appropriately by bodies such as the Arts Council who, at the time, had just announced the withdrawal of funding from Jazz Services. By describing jazz as the 'Cinderella of Arts Funding', Hewett sought to understand why jazz didn't have the cultural status it deserved in the UK, given that audiences for jazz rivalled that for opera and that the music was performed in such a broad range of settings, from pubs to concert halls. Hewett's conclusion was that, in the UK in particular, the image of jazz remains a problem; in effect, policy makers and funders can't take jazz seriously as it is difficult to shed the image of jazz as something comical, bound up with a generation of post-war traditionalists such as George Melly and Acker Bilk. ${ }^{7}$ In other words, despite the desire to be considered 'grown up', jazz just cannot shake off its immature image and is understood as something stuck in the past.

In broader contexts, Europe has continued to serve as an important site for the appreciation and recognition of jazz, as audiences have engaged enthusiastically with American artists. In turn, Europe enabled American musicians to change their lifestyles and explore new creative outlets for their music; this ranged from Dexter Gordon's work in Copenhagen throughout the 60s and early 70s to the Art Ensemble of Chicago's tenure in Paris in the late 1960s/early 1970s. Indeed, Europe's own history of supporting modernist art is often invoked in narratives of European jazz and the depiction of the growing legitimacy of the music. One only needs to think of the number of post-war improvising collectives ${ }^{8}$ or the evolving visual and sonic aesthetic of the ECM label ${ }^{9}$ to get a sense of how jazz has been used as a symbol of renewal or recalibrated to fit within an existing paradigm of European modernist art.

\section{Developing a sense of the past/Constructing the European jazz tradition}

With the process of growing up, there comes a developing sense of time; in other words, what has happened in the past has led us to the position we find ourselves in today. In essence, as grown-ups, we are both able and find it necessary to narrate our pasts, to develop understandings of where we've come from, and to draw on a sense of history to explain who we are today. This point ties in with the need to construct and identify a coherent tradition for the music. Within post-war US jazz literature, for example, there emerged a discernible need to present jazz as a homogenous tradition that could be celebrated and documented separately from other musics. Equally, the economic and social circumstances of the post-war period led to a change both in generational attitudes and the means of technological production and reception, which inevitably led to the perceived demise of the 'golden era' of jazz.

7 Ivan Hewett, 'Jazz: the Cinderella of Arts Funding', The Telegraph, published 17 July 2014, www.telegraph.co.uk/culture/music/worldfolkandjazz/10971234/Jazz-the-Cinderella-of-arts-

funding.html, accessed 19 October 2017.

8 Nicholas Gebhardt and Tony Whyton, eds., The Cultural Politics of Jazz Collectives: This Is Our Music! (New York: Routledge, 2015).

9 Steve Lake and Paul Griffith, eds., Horizons Touched: The Music of ECM (London: Granta Books, 2007). 
In the US, from the late 1950s on, the shift in status for jazz was evidenced through a wide range of cultural pursuits and activities, from classically-influenced jazz works of the Modern Jazz Quartet, Dave Brubeck and Gunther Schuller_whose ‘Third Stream' conception encouraged a new hybrid ${ }^{10}$ - to musicians such as Ornette Coleman and John Coltrane and their pursuit of free or collective improvisation, spiritually-inspired compositions, and experimental techniques. This period contained a melting pot of tensions within jazz discourse, from the struggle over the ownership of jazz in critical and artistic terms, to race politics, and to the relationship of jazz to the marketplace. As John Gennari states, Jazz was commerce, and jazz was art, but exactly where jazz should be positioned in relation to other cold war-era commercial culture and artistic discourses was a matter of concern. ${ }^{11}$ Gennari argues that, come the early 1960s, the contestations and changes in the cultural landscape for jazz brought about a renewed aesthetic for the music, with jazz writers and the industry at large placing emphasis on themes of maturity and cerebral sophistication instead of physical abandon and youthful hedonism. Writers such as Gunther Schuller and Martin Williams emerged during this period with a deeply felt passion to promote the heritage of jazz and the artistic qualities of the music, therefore reinforcing the idea in America that jazz had 'grown up'. Essentially, these writers sought to map across the value systems of the great literary tradition and the formalist methods of classical musicology to demonstrate how serious and enlightening jazz was, and to write about works that constituted the essential building blocks of jazz history. For example, Williams' collection of writings, The Jazz. Tradition - a title clearly paying homage to F. R. Leavis's The Great Tradition ${ }^{12}$ - was first published in 1970, and his work on the Smithsonian Collection of Classic Jazz in 1973 categorised the seminal recordings of jazz history, cementing the notion of a canon of timeless jazz masterworks. ${ }^{13}$ Throughout the 1970 s there was an interest in repertory ensembles, which established an official body of jazz works, as well as a renewed interest in earlier forms of jazz among audiences and jazz labels; ultimately, the historicising of jazz became a crucial means of combating the supposedly corrupting influence of the present and detaching 'classic' jazz from the changing whims of popular culture. ${ }^{14}$ Developments in European jazz in this same period should not be divorced from their American counterparts. Indeed, the construction of the jazz tradition in America-with its related archives, museums, and canon of great masterworks-

10 Gunther Schuller, Musings: The Musical Worlds of Gunther Schuller (Oxford and New York: Oxford University Press, 1986).

11 John Gennari, Blowin' Hot and Cool: Jazz and its Critics (Chicago and London: University of Chicago Press, 2006), 178.

12 Frank Raymond Leavis, The Great Tradition (London: Faber \& Faber, 2008 [11948]).

13 Martin Williams, The Jazz Tradition (Oxford: Oxford University Press, 1993 [11970]); Smithsonian Collection of Classic, compiled by Martin Williams (LP box set, Smithsonian Institution, 1973).

14 For a further discussion of jazz's changing relationship with popular culture during this time, see Tony Whyton, 'Introduction: The Changing Discourse of Jazz as Popular Music', in Jazz, ed. Tony Whyton (Aldershot: Ashgate, 2011), xi-xxiii. For further details about the changing discourse of jazz history and the construction of tradition, see Scott DeVeaux, 'Constructing the Jazz Tradition: Jazz Historiography', Black American Literature Forum 25, No. 3 (Autumn 1991), 525-560. 
arguably paved the way for new traditions to emerge in different European contexts. Following on from the development of the Smithsonian Classic Jazz Collection and other US-based historicising projects such as the NEA Jazz Oral History Project (1971-1984), the majority of jazz archives and oral history projects in Europe were founded in the 1980s, when the history of national jazz scenes and the contributions of musicians and writers were given greater recognition. Examples include the establishment of the Jazz Institute in Darmstadt, which emerged from the city acquiring the works of well-known jazz critic and producer Joachim Ernst Berendt in 1983, or the British Library's 'Oral History of Jazz in Britain' that sought, among other things, to shed light on 'the influx and impact of musicians from overseas' and 'Britain's crucial role in the development of free improvisation in the $1960 \mathrm{~s} .{ }^{, 15}$

\section{Moving to Higher Ground: jazz as 'Art', not popular music}

Finally, growing up also has a dynamic quality, suggesting motion, a type of development, or movement in an upward trajectory. The idea of growing up could also mean that jazz itself was upwardly mobile at this time, music on the move. If we grow up we also have to entertain the possibility of leaving people behind, or viewing life afresh from our heightened position; there is a certain elevation to growing upwards where we see the world from above, develop a new perspective, and also have the potential to look down on others. Perhaps, to coin Wynton Marsalis's book title, this period is responsible for jazz 'Moving to Higher Ground'; ${ }^{16}$ growing up in this way perhaps offers us a spiritual dimension, where we become closer to transcendent experiences when on high. Within this context, dominant jazz narratives have promoted the spiritual qualities of the music from the 1960s onwards, coupled with a commitment to canonical aesthetics in which jazz is understood as art music as opposed to popular music. In effect, as a canonical art form, jazz is often presented as autonomous art, thus mirroring the problematic discourse of Western art music. Framing jazz as 'grown up' in this way, therefore, suggests that the music has developed a universality and artistic credibility that divorces it from popular culture and the trappings of everyday life. The creation of a divide between high and low culture might help to justify subsidy for jazz as a marginalised art form, but the perpetuation of binaries such as these inevitably diminish the impact and value of jazz in different cultural settings. Here, we should be mindful that jazz continues to play a central part in popular music discourse, from being the focus of early critiques of the culture industry to the recognising the music's important place within film and television industry today. Despite the continued detachment of the terms 'jazz' and 'popular music' in pedagogical and research terms, jazz has not only provided one of the central foundations in popular music studies but has also continued to play a complex and integral role in the workings of popular culture.

15 'Oral History of Jazz in Britain', British Library, accessed 20 October 2017, http://sounds.bl.uk/jazzand-popular-music/oral-history-of-jazz-in-britain.

16 Wynton Marsalis with Geoffrey Ward, Moving to Higher Ground: How Jazz Can Change Your Life (New York: Random House, 2008). 
As the study of popular culture gained legitimacy and momentum in the post-war period, jazz remained an essential ingredient in promoting the value of popular music in the emerging cultural studies movement, being used by scholars to explain the positive contribution of popular culture to society at large. Stuart Hall and Paddy Whannel's 1964 book The Popular Arts, for example, offered jazz as one of the legitimate forms of popular culture to study and analyse. ${ }^{17}$ Within this context, the earlier damning attacks on mass culture by figures such as Theodor Adorno could be countered by arguing that a discerning audience was the key to ensuring that 'good' popular culture could be appreciated over 'bad' popular culture. Here, jazz was presented as 'infinitely richer' than pop music on both aesthetic and emotional levels, having the ability to extend musical tastes and pleasures. ${ }^{18}$ In evaluating The Popular Arts, John Storey states that Hall and Whannel's position struggles to 'free itself from the theoretical constraints of Leavisism: teenagers should be persuaded that their taste is deplorable and that by listening to jazz instead of pop music they might break out of imposed and self-imposed limitations'. ${ }^{19}$ Whether intended or not, jazz's separation from the supposedly negative aspects of popular culture served to intensify the distinctions between jazz and the commercial industry. This separation perpetuated the notion of 'high' and 'low' both within and outside the boundaries of popular culture.

The canonical story of jazz focuses on the unity of the whole and portrays history as a straightforward causal narrative, devoid of conflict and contestation. Inevitably, the celebration of the canon has resulted in creating an artificial divide between understanding jazz as an integral part of popular culture and promoting the music as part of a homogenous tradition. As a canonical art, jazz is portrayed as a universal and transcendent music, mirroring the ideals of western classical music and, therefore, continuing to reinforce the constructs of high and low culture.

As Alastair Williams points out in Constructing Musicology, the overtly socialised medium of popular music has appeared trivial alongside autonomous art forms in the past. ${ }^{20}$ Within this context, promoters of the linear tradition have inevitably sought to subvert jazz's links to popular culture in order to preserve the autonomy and integrity of the canonical whole.

\section{Conclusion: challenging binaries}

Where does this leave us as 'grown-ups' seeking to make sense of the changing discourse of European jazz? In my recent work, I've been keen to develop strategies that resist reducing jazz scenes, cultures and histories into simplistic oppositional categories. Indeed, in my work on the

17 Stuart Hall and Paddy Whannel, The Popular Arts (London: Hutchinson Educational, 1964)

18 Hall and Whannel, The Popular Arts, 311-312.

19 John Storey, Cultural Theory and Popular Culture: An Introduction (Harlow: Pearson Education Limited, 2006 [11997]), 43. Leavisism refers to a form of literary studies as advocated by F. R. Leavis, where high culture is understood to be the preserve of an elite or minority group.

20 Alastair Williams, Constructing Musicology (Aldershot: Ashgate, 2007), 76. 
legacy of John Coltrane, I explored the way in which binaries shape the romantic and mythological discourses of jazz, whether they reinforce stereotypes linked to race, gender or place or are used to privilege certain types of jazz practice over others (art over commerce and popular culture, live over recorded etc.). ${ }^{21}$ One can easily get a sense of binaries at play within discourses of jazz between 1960 and 1980. For example, take the depictions of Dexter Gordon's return to New York in 1976, where his homecoming not only served as a sign that the jazz tradition could be revived and continued but it was also marked as a return from the 'wilderness'; as if Europe represented a distant land where musicians were lost and needed to be found. ${ }^{22}$ The theme of growing up also fuels binaries in some way-inviting us to think about what we were before we grew up, being emancipated etc. From my perspective, whether we are considering jazz as art, the music's relationship to popular culture, tradition, America or Europe, we must consider these categories as interdependent and part of a much more complex system of influence and cultural exchange.

In my Coltrane Book Beyond A Love Supreme, I drew on the anthropological work of Steven Feld to provide an illustration of the complexity of cultural exchange in jazz. ${ }^{23}$ Feld's Jaz: Cosmopolitanism in Accra explored the idea of cultural exchange, genealogies of listening and the flow of influences and ideas among a community of musicians in Accra and the presence of Coltrane as a cosmopolitan influence. ${ }^{24}$ One example I drew on in my study was the way in which Feld described how Ghanaian musicians have used the music of Coltrane as a way of exploring and constructing their own African identity. Coltrane had never visited Africa and yet his African-themed works have encouraged Accra-based musicians to explore their sense of place and challenge official narratives of music and nationhood. For me, this provided a complex example of how culture is exchanged and how identities are constructed. To emphasise the significance of this example and move the discussion away from Coltrane and Africa to a more broad-based discussion of cultural influence and exchange, I asked the Lucerne Conference audience to imagine a Japanese musician never visiting Switzerland but composing music that constructed a vision of what it was to be Swiss 50 years ago and, subsequently, Lucerne-based musicians using this Japanese impression of Switzerland to explore, create, and imagine a sense of their own national identity today. When thought of in this way, the uses and influences of culture clearly flow in multiple directions and cannot be reduced to simple binaries, boundaries and border controls.

More than anything, the theme of growing up provides us with a powerful example of the way in which language helps to frame our understanding of the world; its connotative power

21 Tony Whyton, Beyond A Love Supreme: John Coltrane and the Legacy of an Album (New York: Oxford University Press, 2013).

22 For further commentary on Dexter Gordon's 'homecoming' see Stuart Nicholson, Jaz: The 1980s Resurgence (New York: Da Capo, 1995), 71-74.

23 Whyton, Bevond A Love Supreme, 121-122.

24 Steven Feld, Jazz Cosmopolitanism in Accra: Five Musical Years in Ghana (Durham and London: Duke University Press, 2012). 
can construct and reinforce a series of values that are bound up with music and its place in society. Indeed, considering the Lucerne Conference programme, I suggested to the audience that the event would have had a very different feel if instead of having to respond to the theme of 'Growing Up' we were instead invited to 'Get Down' with jazz within the same time period. This comment not only demonstrated how language and the phraseology we use encourages certain responses in people, but it was also used to illustrate how humour can be used to question and subvert dominant representations of music. Indeed, humour is perhaps a trait that, in the context of growing up, we can often lose sight of. Rather than growing up leading to a position where we are taken more seriously, we could also consider the act of growing up as giving us a platform for self-reflection, critique and, when the occasion suits, self-deprecation. When applied to jazz, I would argue that humour in different forms has been essential to the vibrancy of the music past and present. Indeed, we can all think of examples of humour in jazz whether musical or part of the broader representations of the form; one only needs to consider the recent satirical piece on Sonny Rollins in The New Yorker, ${ }^{25}$ Django Bates's musical parody of New York, New York, or Will Ferrell's jazz flute performance as Ron Burgundy in the film Anchorman to get a sense of how jazz is used as an object of parody. These comedic representations might be annoying for some; however, as with the claims of jazz being high art, they are also important demonstrations of the music's continuing cultural worth. Parody is an important jazz trait, both in the music and in jazz discourse, that creates a tension between the parody itself and the original work in question. It takes a sophisticated understanding of codes and conventions in order for parody to work effectively and, through time, jazz musicians have been incredibly adept at critique, whether through musical responses to other works or by employing humour as a form of social and political commentary. When applied more broadly to culture, the politics of humour can lead us into a much deeper understanding of the world and the power relationships at play between people and different social groups. Through the lens of humour, we can be encouraged to read and re-read music with new eyes and to develop understandings of the complex role that jazz performs in everyday life. Whilst parody and satire can provide us with a useful set of tools to subvert dominant meanings, challenge power structures and examine social taboos, we also need to continually remind ourselves of the balance between ethics and aesthetics and the power structures at play; who is mocking who and why.

To conclude, the theme of growing up has offered a useful way in to considering some of the issues at play in jazz today and the way in which the development of jazz in Europe has been framed to date. When considering the power of language to connote and invite responses, we must also acknowledge that history is not only lived but is also constructed retrospectively to suit the needs, desires and values of the present day. With this in mind, I would suggest that

25 Django Gold, 'Sonny Rollins: In His Own Words', The New Yorker, 31 July 2014, accessed 20 October 2017, www.newyorker.com/humor/daily-shouts/sonny-rollins-words. 
growing up should also lead to a sense of self-reflection, the ability to acknowledge our biases and agendas, to challenge the way we've seen the world up until this point and the part we all play in the construction and perpetuation of values bound up with the music. When we achieve this, we can finally celebrate our coming of age. 